\title{
EMOTIONS AND NEGATIVITY
}




\section{RESEARCH ON EMOTION IN ORGANIZATIONS}

\section{Series Editors: Wilfred J. Zerbe, Charmine E. J. Härtel and Neal M. Ashkanasy}

\section{Recent Volumes:}

Volume 1: The Effect of Affect in Organizational Settings

Edited by Neal M. Ashkanasy, Wilfred J. Zerbe and Charmine E. J. Härtel

Volume 2: Individual and Organizational Perspectives on Emotion Management and Display

Edited by Wilfred J. Zerbe, Neal M. Ashkanasy and Charmine E. J. Härtel

Volume 3: Functionality, Intentionality and Morality

Edited by Wilfred J. Zerbe, Neal M. Ashkanasy and Charmine E. J. Härtel

Volume 4: Emotions, Ethics and Decision-making

Edited by Wilfred J. Zerbe, Charmine E. J. Härtel and Neal M. Ashkanasy

Volume 5: Emotions in Groups, Organizations and Cultures Edited by Charmine E. J. Härtel, Neal M. Ashkanasy and Wilfred J. Zerbe

Volume 6: Emotions and Organizational Dynamism

Edited by Wilfred J. Zerbe, Charmine E. J. Härtel and Neal M. Ashkanasy

Volume 7: What Have We Learned? Ten Years on Edited by Charmine E. J. Härtel, Neal M. Ashkanasy and Wilfred J. Zerbe

Volume 8: Experiencing and Managing Emotions in the Workplace Edited by Neal M. Ashkanasy, Charmine E. J. Härtel and Wilfred J. Zerbe 
Volume 9: Individual Sources, Dynamics, and Expressions of Emotion Edited by Wilfred J. Zerbe, Neal M. Ashkanasy and Charmine E. J. Härtel

Volume 10: Emotions and the Organizational Fabric

Edited by Neal M. Ashkanasy, Wilfred J. Zerbe and Charmine E. J. Härtel

Volume 11: New Ways of Studying Emotion in Organizations Edited by Charmine E. J. Härtel, Wilfred J. Zerbe and Neal M. Ashkanasy

Volume 12: Emotions and Organizational Governance

Edited by Neal M. Ashkanasy, Charmine E. J. Härtel and Wilfred J. Zerbe

Volume 13: Emotions and Identity

Edited by Wilfred J. Zerbe, Charmine E. J. Härtel, Neal M. Ashkanasy and Laura Petitta

Volume 14: Individual, Relational, and Contextual Dynamics of Emotions Edited by Laura Petitta, Charmine E. J. Härtel, Neal M. Ashkanasy and Wilfred J. Zerbe

Volume 15: Emotions and Leadership Edited by Neal M. Ashkanasy, Wilfred J. Zerbe and Charmine E. J. Härtel

Volume 16: Emotions and Service in the Digital Age Edited by Charmine Härtel, Wilfred J. Zerbe and Neal M. Ashkanasy 
This page intentionally left blank 
RESEARCH ON EMOTION IN ORGANIZATIONS VOLUME 17

\title{
EMOTIONS AND NEGATIVITY
}

\author{
EDITED BY \\ RONALD H. HUMPHREY \\ Lancaster University Management School, UK \\ NEAL M. ASHKANASY \\ The University of Queensland, Australia \\ And
}

ASHLEA C. TROTH

Griffith University, Australia

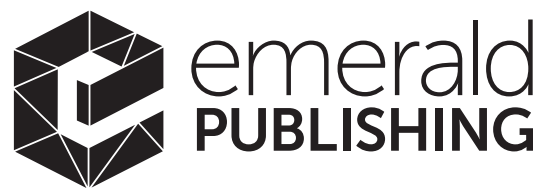

United Kingdom - North America - Japan India - Malaysia - China 
Emerald Publishing Limited

Howard House, Wagon Lane, Bingley BD16 1WA, UK

First edition 2022

Copyright $\odot 2022$ by Emerald Publishing Limited

\section{Reprints and permissions service}

Contact: permissions@emeraldinsight.com

No part of this book may be reproduced, stored in a retrieval system, transmitted in any form or by any means electronic, mechanical, photocopying, recording or otherwise without either the prior written permission of the publisher or a licence permitting restricted copying issued in the UK by The Copyright Licensing Agency and in the USA by The Copyright Clearance Center. Any opinions expressed in the chapters are those of the authors. Whilst Emerald makes every effort to ensure the quality and accuracy of its content, Emerald makes no representation implied or otherwise, as to the chapters' suitability and application and disclaims any warranties, express or implied, to their use.

\section{British Library Cataloguing in Publication Data}

A catalogue record for this book is available from the British Library

ISBN: 978-1-80117-201-1 (Print)

ISBN: 978-1-80117-200-4 (Online)

ISBN: 978-1-80117-202-8 (Epub)

ISSN: 1746-9791 (Series)

\section{ISOQAR certified}

Management System,

awarded to Emerald

for adherence to

Environmental

standard

ISOQAR

ISO 14001:2004 


\section{CONTENTS}

About the Editors xi

About the Contributors xiii

Introduction: Emotions and Negativity 1

Ronald H. Humphrey, Neal M. Ashkanasy and Ashlea C. Troth

\section{PART I \\ NEGATIVE EMOTIONS AND COPING STRATEGIES}

The Emotions of Failure in Organizational Life

Roy K. Smollan and Smita Singh

Exploring the Emotional Experiences and Coping Strategies of Sustainability Change Agents

Sally V. Russell and Stephanie Victoria

Can Social Rejection Change Employees' Value Priorities? The Mediating Roles of Emotional Distress and Emotional Numbness

Mahsa Amirzadeh, Neal M. Ashkanasy, Hamidreza Harati,

Justin P. Brienza and Roy F. Baumeister

Job Insecurity, Emotional Skills, Workplace Emotional

Reactions, and Decision-making Behaviors

Peter J. Jordan, Neal M. Ashkanasy and Sandra A. Lawrence

\section{PART II \\ EMOTIONAL REGULATION AND EMOTIONAL LABOR}

"Discretion Remains the Rule": A Multilevel Study of Emotional Requirements in a Public Hospital

Rebecca Dickason 
Emotional Labor Work Attributes and Emotional Labor Climate: Toward Contextualizing the Study of Emotional Labor Andrea Fischbach and Benjamin Schneider

Unfulfilled Entitlement Beliefs and Employee's Emotion Regulation Motives and Job Satisfaction: A Conceptual Model 161 Dan H. Langerud, Peter J. Jordan, Matthew J. Xerri and Amanda Biggs

Receiver's Experience of and Response to Anger in the Workplace 177 Kathryn E. H. Moura, Ashlea C. Troth and Peter J. Jordan

\section{PART III \\ MANAGERS AND LEADERS}

Supervisor Family Support and Job Performance: Effects of Demand, Conflict, Balance, and Attitude A K M Mominul Haque Talukder

How Supervisors' Compassionate but Unethical Behavior Impacts Subordinates' Unethical Behavior: A Sensemaking Process

Hongguo Wei, Shaobing Li and Yunxia Zhu

The What and How of Positive Feedback: A Review and Experimental Study of Positive Feedback "Best Practices"

Elena Svetieva and Paulo N. Lopes

\section{PART IV CONCLUSIONS}

Solutions to Negative Emotions

Ronald H. Humphrey, Neal M. Ashkanasy and Ashlea C. Troth 
Dedicated to former series editors Wilfred J. Zerbe and Charmine E. J. Härtel who have contributed so greatly to the Emonet group since the beginning in 1998, including cochairing 11 Emonet conferences and coediting no less than 19 conference-based edited volumes. The success of the Emonet group and the REOM book series largely reflects their energy and dedication. Thanks guys! 
This page intentionally left blank 


\section{ABOUT THE EDITORS}

Neal M. Ashkanasy OAM, PhD, is Professor of Management at the UQ Business School (The University of Queensland, Australia). He studies emotion, leadership, culture, and ethical behavior. He has published over 100 refereed articles, including leading journals such as AMJ, AMR, and JAP. He served as Editor-inChief of the Journal of Organizational Behavior and Associate Editor for the Academy of Management Review and Academy of Management Learning and Education. He is a Fellow of several learned societies (ANZAM, APS, ASSA, BAM, SIOP, SMA) and the 2019 Academy of Management Managerial and Organizational Cognition Division Distinguished Scholar.

Ronald H. Humphrey is a Distinguished Professor of Leadership in the Lancaster University Management School (UK). Ron is dedicated to helping people develop an empathic and emotionally intelligent leadership style. He and his coauthors have gathered the largest amount of independent evidence on the validity of emotional intelligence in the workplace. He is among the top scholars in the world in his research areas as measured by the number of citations according to keywords listed on Google Scholar Profiles (for emotional labor, ranked 3rd, for empathy, ranked 5th, for emotional intelligence, ranked 11th).

Ashlea C. Troth is a Professor in Organizational Behavior at the Business School in Griffith University, Australia. Her research examines workplace emotions, emotional intelligence, and emotion regulation in organizational and leadership contexts. She has been a grant recipient of both the Australian Research Council Discovery and the Centre for Workplace Leadership at the University of Melbourne. Ashlea was recognized as part of the best research team at Griffith Business School 2016. She has 20 years' experience as a consultant, facilitator, and researcher in the field. Ashlea also has various research and consulting experiences with Queensland Health, a local council, a commonwealth agency, and a pathology agency. 
This page intentionally left blank 


\section{ABOUT THE CONTRIBUTORS}

Mahsa Amirzadeh is a PhD Candidate at the University of Queensland Business School. Her dissertation deals with the effects of Social Rejection on Human Values. She tries to apply her findings to organizational setting and uses experiments to test her hypotheses. Mahsa holds a MSc in Organizational Behavior from Tarbiat Modares University and a BA in Marketing from the University of Tehran.

Neal M. Ashkanasy OAM, PhD, is Professor of Management in the UQ Business School at the University of Queensland, Australia. He studies emotion in organizations, leadership, culture, ethical behavior, and the physical environment of work. He has published in journals such as the Academy of Management Journal and Review, the Journal of Management, and the Journal of Applied Psychology. He served as Editor-in-Chief of the Journal of Organizational Behavior, Associate Editor for the Academy of Management Review and Academy of Management Learning and Education. He is currently Associate Editor for Emotion Review and Series Editor for Research on Emotion in Organizations. He is the founder and administrator of the Emonet Listserv. In 2017, he was awarded a Medal of the Order of Australia (OAM), and in 2019 he was named the Academy of Management's Managerial and Organizational Psychology Division Distinguished Scholar.

Roy F. Baumeister is a Psychology Professor at the University of Queensland. He received his $\mathrm{PhD}$ in Social Psychology from Princeton in 1978 and did a postdoctoral fellowship in Sociology at the University of California at Berkeley. Baumeister's research spans multiple topics, including self and identity, selfregulation, interpersonal rejection, and the need to belong, sexuality and gender, aggression, self-esteem, meaning, and self-presentation. He has nearly 700 publications, and his 42 books include Evil: Inside Human Violence and Cruelty, The Cultural Animal, Meanings of Life, and the New York Times bestseller Willpower: Rediscovering the Greatest Human Strength. Other scientists have referred in their publications to his work over 20,000 times, making him among the handful of most cited (most influential) psychologists in the world. He has received several major awards, including the William James Fellow award (their highest honor) from the Association for Psychological Science.

Amanda Biggs is a Lecturer at the Griffith Business School, Griffith University, Australia. Amanda's research interests encompass the management of psychological and physical health at work, including work engagement, stress, bullying, healthy behaviors, and positive organizational cultures. 
Justin P. Brienza is an Assistant Professor/Lecturer at the University of Queensland Business School in Queensland, Australia. His research bridges social-organizational phenomenon with a focus on reasoning, bias, balance, and wisdom. He received his Hons. BSc from the University of Toronto with a double major in Cognitive Science and A.I \& Psychology, and his MA and $\mathrm{PhD}$ in Industrial/Organizational Psychology. Justin's PhD research reconceptualizing measurement of wisdom-related qualities served to spark new directions in research on wisdom and its application to various social-organizational problems such as conflict management, interpersonal and group cooperation, and intergroup bias and attitude polarization in modern societal conflicts. Currently, Justin is investigating practical applications for wisdom-related cognitions in the context of management decision-making, organizational change (e.g., policies and processes) negotiations, interdisciplinary collaboration, democratic decision making, societal well-being, as well as leadership and leader training and development practices.

Rebecca Dickason is Associate Professor at the Institute for Management Research (IRG), Gustave Eiffel University (Paris, France). She specialized in Organizational Behavior and Management before studying Public Health in parallel to writing her $\mathrm{PhD}$ dissertation. A keen observer of healthcare settings for many years, she prepared her Doctorate partly at the French School of Public Health (EHESP) and focused on the emotional labor of hospital healthcare professionals. Emotions are the cornerstone of her research topics which comprise emotional processes and competencies at work, occupational health, and organizational resilience. How time, space, rules, and emotions intertwine are of particular significance to her, as is the role of emotion and compassionrelated factors in the quality of care and in occupational health. Her research interests include other organizational settings; for instance, she has recently started a study on the impact of the current Covid-19 crisis on management practices and remote working.

Andrea Fischbach is Full Professor of Social, Work, and Organizational Psychology at the German Police University, Münster. She received her Diploma in Psychology at Goethe-University, Frankfurt, Germany, her PhD at GeorgAugust-University, Göttingen, Germany, and she has held a JuniorProfessorship for Organizational Psychology at Trier University, Germany. She has published more than 65 professional journal articles and book chapters on emotional labor, job crafting, organizational justice, and work diversity (age/ gender/culture), and their implications for both performance and worker health. She has led several funded research projects (1+ Million Euros) including a threeyear project on emotional labor in retail stores. She coedited with Benjamin Schneider the Special Issue of the Journal of Service Management Research, Emotional Labor and Service. Her research focuses on the dynamics of work conditions, leadership, and HR management to help understand what makes people engaged, motivated, and healthy at work. 
Hamidreza Harati is a $\mathrm{PhD}$ candidate at the University of Queensland Business School. Before his appointment, he was a visiting scholar at the same faculty from 2017 to 2018. He came to academia after a 6-year career as a senior management consultant. His diverse research interests cover feedback in the workplace, cross-cultural management, workplace aggression, business ethics, and emotional well-being. His $\mathrm{PhD}$ thesis investigates the effect of different types of negative feedback on employee performance. He has also presented his research at international conferences such as the Southern Management Association, British Academy of Management, Society for Personality and Social Psychology, Australian and New Zealand Academy of Management.

Ronald H. Humphrey is a Distinguished Professor of Leadership in the Lancaster University Management School (UK). Ron is dedicated to helping people develop an empathic and emotionally intelligent leadership style. He and his team have gathered the largest amount of independent evidence on the validity of emotional intelligence in the workplace. He also studies emotional labor, authentic leadership, servant leadership, personality traits, leadership emergence, identity theory, emotions in the workplace, and other topics. He has published two books, Effective Leadership: Theories, Cases, and Applications, and Affect and Emotion: New Directions in Management Theory and Research (editor).

Peter J. Jordan is a Professor of Organizational Behavior and Acting Director of the Work Organization and Wellbeing Research Centre at the Griffith Business School, Griffith University. He gained his PhD in Management at the University of Queensland. Peter's current research interests include emotional intelligence, emotions in organizations, team performance, and entitlement. Peter has published extensively in this field in leading international journals and has been awarded funding from the Australian Research Council for research in the area of emotional intelligence.

Dan H. Langerud is a $\mathrm{PhD}$ candidate at the Griffith Business School, Griffith University, Australia. Dan's research focuses on employee's entitlement perceptions and how these are expressed in the workplace.

Sandra A. Lawrence graduated with a PhD from the University of Queensland in 2006 and is a Senior Research Fellow in the Centre for Governance and Public Policy at Griffith University in Brisbane, Australia. In her research, Dr. Lawrence focuses on the role of human resource management (HRM), work teams, frontline managers, and employees themselves in optimizing employee and organizational performance. Dr. Lawrence holds research expertise in the areas of HR functions and hospital clinical performance; workplace emotions and performance in work teams; frontline manager influence on employee behaviors and employees' EI and emotional regulation in dealing with workplace anger. She has published her work in the Journal of Applied Psychology, the Journal of Organizational Behavior, and the International Journal of Management Reviews. 
Shaobing $\mathbf{L i}$ is an entrepreneur in a start-up company called Speak Yourself. He studied moral character and ethical leadership from an experiential perspective for his Doctorate on educational leadership at Miami University. In particular, his research interests include moral character, multicultural education, and ethical leadership. He is passionate about applying moral character and moral development to educational and business practice.

Paulo N. Lopes works in business and social entrepreneurship, executive education, consulting, and research. He holds a BA in Economics and PhD in Psychology from Yale University. His teaching and consulting work bridges leadership development, innovation, and change management. He is particularly interested in helping organizations develop collective leadership, mobilizing group intelligence and creativity to address organizational challenges. At Católica-Lisbon School of Business and Economics, he cocoordinates the "Leading and Energizing Teams" program. In his earlier career, he worked in journalism, documentary filmmaking, management, and academia. He was a Fulbright scholar and Senior Lecturer in Psychology at the University of Surrey in the United Kingdom. His research on emotional abilities and emotion regulation, published in numerous international journals, explored implications for personal and professional development.

Kathryn E. H. Moura graduated with a PhD from Griffith University in 2021. Her main area of research is in emotions, more specifically, anger within the workplace. Kathryn has extensive cross-cultural and human resource management experience, having lived and worked on three continents. Kathryn's experience includes being one of the directors of an international company for 14 years, founding her own company, and working in HR consulting, training, and business coaching.

Sally V. Russell is Associate Professor of Business, Organizations and Sustainability at the Sustainability Research Institute at the University of Leeds. With a background in organizational behavior and environmental psychology, Sally's research focuses on behavior change for sustainability and examines factors that affect individual and organizational responses to environmental issues. She has a particular interest in the emotions as they relate to the work of sustainability professions, and the role of emotions as a driver of sustainable behavior both within and outside organizational contexts. In all areas of her research, Sally works closely with industrial partners to ensure that her research contributes practically and scientifically to the development of more sustainable ways of doing business.

Benjamin Schneider is Professor Emeritus of Psychology at the University of Maryland and Affiliate Research Scientist at the Center for Effective Organizations, the University of Southern California. Ben has published more than 125 professional journal articles and book chapters and 12 books, with a 13th on work engagement coedited with John Meyer recently published by Elgar. Ben's interests concern organizational climate and culture, service quality, work 
engagement, staffing organizations, and the role of personality in organizational life. Since retiring from Maryland, he has worked with several research and consulting firms (Valtera, CEB, and PDRI) on these topics and independently as an organizational diagnostician helping organizations identify how they are handling these human issues. Ben has won distinguished research contributions awards from numerous professional societies and he has also served as President of SIOP and of the OB Division of the Academy of Management. More details are available at www.DrBenSchneider.com.

Smita Singh is a Senior Lecturer at the Auckland University of Technology (AUT), New Zealand. Smita's PhD research explored experiences of failure in entrepreneurship. Underpinning her research is a passion for illuminating the human side of work and enterprise. Thereby, her research investigates the interplay between working for ventures and people's well-being, with particular focus on the possibilities of growth and development that lie within the silent experiences of loss, 'taken-for-granted' cultural taboos, and the hidden stories of stigmatized conditions. She crosses disciplinary boundaries to explore such topics and contexts that shapes entrepreneurs' lives, their work, and the social impact of their enterprise on communities they aim to serve. More recently, this focus also includes academic work and life, which inevitably shapes students' preparedness for future work.

Roy K. Smollan, PhD, is a Senior Lecturer in Management at the Auckland University of Technology, Auckland, New Zealand. His research interests lie in the fields of organizational change, organizational culture, social entrepreneurship, occupational stress, emotions at work, emotional intelligence, leadership and organizational justice. He has published a number of journal articles and book chapters on these constructs. As the corresponding author he can be contacted at: roy.smollan@aut.ac.nz.

Elena Svetieva is Assistant Professor and Director of Leadership Communication at the University of Colorado, Colorado Springs (UCCS). Prior to joining the faculty at UCCS, Elena was a postdoctoral fellow at the Center for Creative Leadership in Greensboro, North Carolina and the Católica-Lisbon School of Business and Economics in Lisbon, Portugal. Elena teaches courses in Leadership Theory and Practice and Organizational Leadership. Elena's research focuses on the emotional dimensions of communication, whether it be facial expressions of emotion in political leaders, or leader emotion in communicating feedback to subordinates. She is also interested in the intersection between emotion and deception and how emotion influences the way we lie and our decision to do so. Elena holds a PhD in Communication from the State University of New York at Buffalo and BA in Psychology from the University of Sydney.

A K M Mominul Haque Talukder is a Postdoctorate Fellow at Peter B. Gustavson School of Business, University of Victoria, Canada. He obtained his Doctorate from Western Sydney University where his dissertation explored the influence of supervisor's family support on job performance through perceived work and 
family demand, work and family conflict, work-life balance, and work and life attitude. At present, he is delving into work stress, work-life balance, and employee resilience, with two new projects first, by examining the roles of employee resilience can play in organizations and second, evaluating change in stress over time, using two waves of time panel data. An important goal of this investigation is to contribute to the knowledge set of organizational behavior and human resources on how to design and implement policies and practices mingling work-life balance, resilience, and psychological well-being and how effectively these could bundle to gain competitive and sustainable advantages for organizations.

Ashlea C. Troth is a Professor in Organizational Behavior at the Griffith Business School, Griffith University. Her areas of research expertise are in emotional intelligence and regulation, communication, and performance. Ashlea's work has been published in leading international journals and has been awarded funding from the Australian Research Council to examine emotional intelligence and regulation in the workplace.

Stephanie Victoria holds an MSc in Sustainability and Business from the University of Leeds and a BA in Sustainability and the Environment from the Florida International University Honors College. Stephanie's research is centered around emotions in the workplace, with a special focus on behavior and decisionmaking. Her work combines her passion for the environment and her keen interests in psychology and human well-being. Her Masters dissertation studied how sustainability change agents cope with the negative emotions in their work. Her capstone thesis looked at how psychological priming and exposure to different cultures influences business ethical decision-making. Stephanie currently works as a project coordinator at the World Resources Institute and supports the executive office with portfolio management and institutional planning.

Hongguo Wei is an Assistant Professor in the School of Business at Robert Morris University. She is passionate about studying how to improve employee well-being and create a better workplace through the lens of emotions and leadership. In particular, her research interests focus on leadership, emotions, workplace relationships, and ethical behavior. She studied the compassionate interaction between leaders and followers for her Doctorate at Case Western Reserve University. While advocating the positive impact of compassion at work, she also intends to examine how to reduce the adverse impact of compassion by relating to ethical behaviors and motivation literature. She has applied both qualitative and quantitative research methods in her research.

Matthew J. Xerri is a Senior Lecturer at the Griffith Business School, Griffith University, Australia. Matthew's research interests include employee well-being, positivity in the workplace, workplace relationships, and human resources in developing employee outcomes. Matthew also has an interest in public sector management. 
Yunxia Zhu is an Associate Professor of International Management at the University of Queensland Business School, Australia. Her research focuses on organizational learning and cross-cultural management and communication. She is interested in using diversity positively to examine cross-cultural communication interaction and processes in the global workplace. She explores the role moral emotions play in ethical firm decision-making process as part of the wider discourse on organizational ethics and morality in emerging economies. 